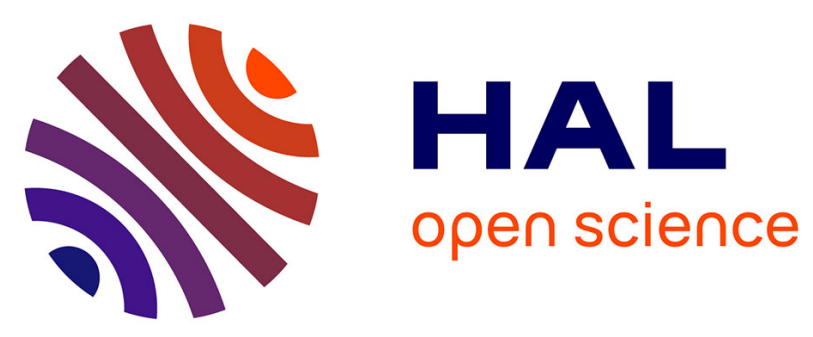

\title{
A Method to Assess Social and Human Factors of Production Innovations
}

Stanislaw Strzelczak, Stanislaw Marciniak

\section{To cite this version:}

Stanislaw Strzelczak, Stanislaw Marciniak. A Method to Assess Social and Human Factors of Production Innovations. IFIP International Conference on Advances in Production Management Systems (APMS), Aug 2018, Seoul, South Korea. pp.433-441, 10.1007/978-3-319-99707-0_54 . hal-02177837

\section{HAL Id: hal-02177837 \\ https://hal.inria.fr/hal-02177837}

Submitted on 9 Jul 2019

HAL is a multi-disciplinary open access archive for the deposit and dissemination of scientific research documents, whether they are published or not. The documents may come from teaching and research institutions in France or abroad, or from public or private research centers.
L'archive ouverte pluridisciplinaire HAL, est destinée au dépôt et à la diffusion de documents scientifiques de niveau recherche, publiés ou non, émanant des établissements d'enseignement et de recherche français ou étrangers, des laboratoires publics ou privés. 


\title{
A Method to Assess Social and Human Factors of Production Innovations
}

\author{
Stanisław Strzelczak ${ }^{[0000-0003-4975-2732] 凶}$ and Stanisław Marciniak \\ Warsaw University of Technology, Faculty of Production Engineering, Warsaw, Poland \\ \{s.strzelczak, iosp@wip.pw.edu.pl\}
}

\begin{abstract}
This paper examines human and social factors of production innovations. An assessment method is proposed to be used for various purposes at the enterprise level. The method is built upon a theoretically justified model that relates human and social endowments to the production innovations as well as the outcomes. The approach derives from the resource based viewing of a strategy process. The holism of assessment is assured by the consideration of crucial interdependencies, the consistency of assessment and the integrity of assessment.
\end{abstract}

Keywords: Holistic assessment, Innovations, Human factor, Social factor

\section{Introduction}

Contemporary business environments require dynamic, innovative and evolutionary capabilities. In such circumstances the effective utilization and the development of human and social capital become key success factor for the sustained competitive performance of industrial firms [1]. Technological change and diffusion (especially in reference to the exponential technologies), rapid innovations and deregulation have eroded the recognized entry barriers, like: technological supremacy, economy of scale, patent protections and government regulations.

Traditionally the economic capital, which comprises financial and material assets, such as equipment and plants, has received all the attention of theory, research, and business practice. In a new economy that recognizes the value from intangible sources, both scholars and managers appreciate equally the importance of human and social capital for economic returns [2].

This paper explores the impact of human and social factors to the innovativeness of industrial firms. We propose a theoretically grounded model that relates human and social endowments to the production innovations as well as the ultimate outcomes. The model is used as the basis for a method for assessing impacts of the both intangible factors. By following the septuple pattern 'objectives-context-perspectivesmodules-subjects-metrics-methods', a reference procedure for a structured assessment was developed. The holism of evaluation is assured by taking into account the viewpoints of all stakeholders as well as all crucial interdependencies between the factors and the primary and secondary effects, and also by securing the consistency and integrity of assessment. 


\section{Background}

The notion of human capital pertains to knowledge, skills and other abilities of individuals that allow for changes in action and economic growth [3]. Basically human capital is developed through education and training. The literature provides evidence of a positive correlation between the human capital, measured by education level and work experience, and the economic performance [4]. Human capital is an important source of competitive advantage to the individuals, organizations and societies [5].

Existing research distinguishes different types of human capital [2]. Firm-specific human capital is expertise, skills and abilities valuable within a specific firm. They may give an advantage over competitors if they are not transferable to other firms [6]. Industry-specific human capital pertains to know-how gathered by learning and experience specific to an industry. It may stimulate innovativeness through social networking and exchanges of tacit know-how among the main players in that industry [7]. Especially the proximity, both in a 'cultural' and geographical sense, within a region or industry, matters in terms of innovation as the exchange of tacit knowledge requires a high degree of mutual understanding [7, 8]. Individual-specific human capital comprises education, vocational training, experience and psychological capital (selfefficacy, creativity, attitudes, resilience, etc.) [1]. The psychological component can be developed following the UX theory, e.g. using mastery experiences, performance attainments, arousal, social persuasion or vicarious experiences [2].

The importance of aligning human capital and corporate strategy with the performance has been supported by an extensive research evidence $[9,10]$. Literature recognizes country level contributions to the human capital, including educational, social, cultural, and welfare factors [11,1].

Social capital refers to the networking, relationships and trust, industrial relations ${ }^{1}$, associational activities ${ }^{2}$ and collective behavior ${ }^{3}$. Unlike the economic view that perceives humans as a resource, social capital applies a sociological view of human actions occurring in groups and teams [2]. The central proposition in the literature on social capital is that networking and relationships provide valuable resources and endowments that can be utilized for the good of an individual or a collectivity [10]. Social capital, like the human one, is being referred to different levels, including the individual, organizational, and societal. At the organizational level, social capital can be defined as the value to an organization from networking and relationships possessed by its members and engaged in collective activities [12]. Prior research emphasizes the role of social capital for innovation and business performance [10, 12], as well as the development of human capital [5].

Literature provides an extensive evidence of positive associations of innovations with the human and social capital, including the following correlating factors:

Industrial relations are relationships and interactions between employees and employers.

Associational activity pertains to the attitudes common in a society to associate or socialize.

3 Collective behavior refers to the attitudes to cooperate and subordinate self-interest for that of the collectivity. Norms of civic and social behavior delimit selfish behavior and encourage individuals to exhibit higher care and concern for the good of public or organizations. 
- level of human capital $[2,10]$;

- external networking, especially for the collaborative innovations [7, 8];

- level of proximity, especially for the collaborative innovations [7, 8];

- level of interpersonal and interorganizational trust [2,7];

- industrial relations [13];

- level of associational activities, both in a company and among organizations [2];

- norms (or level) of collective behavior [2].

The above dependencies apply to radical innovations and continuous improvements.

The assessment and relating of human and social capital with innovations requires quantitative measurement of the factors considered, taking into account the benefits and risks. Measurement of the value derived from intangible sources is a challenge, since it is usually difficult to separate the specific contributions of human and social capital. Literature suggests using direct measures of particular items (natural metrics or Likert-type scales), both leading and lagging, to evaluate specific impacts of human and social factors on innovation and business performance [2]. Adaptation of asset valuation measures (market-to-book ratio, Tobin's Q, etc.) and the method of calculated intangible value (CIV) is also recommended by some authors [14].

Some suggested ways to measure and evaluate social capital involve the size, structure and composition of networks [1]. Another approach derives from the Social Network Analysis (SNA) and suggests such measures as: reciprocity, propinquity, multiplexity, homophily and completeness [15]. Also the theories of social and economic networks offer a range of dynamic models to relate social capital and innovations (e.g. the Axelrod model can be used to analyze the spread of knowledge [16]).

Several innovation indicators are suggested in the literature, like: amount of patents innovations and improvements (both filed and implemented), expenditures and resources dedicated to innovations, level of using innovations, industry-specific yardsticks, outputs and outcomes generated through innovations [2].

\section{Human and Social Factors vs. Innovations and Performance}

According to the literature review in section 2, existing theories perceive human and social factors as essential resources to sustain a competitive advantage. According to the relational view [17] and the theory of factor endowments [18], human and social capital is supplemented by the networking and environmental endowments. This setup is compatible with the resource-oriented structure of the strategy base, which entangles ends (outcomes - competitive performance) and means: resources and strategic capabilities, including innovativeness [19]. Thus, a holistic framework can be derived to relate the human and social factors, the innovativeness and the performance.

Holistic assessment respects all stakeholders by the multi-perspective viewing of a domain [19]. In reference to the paradigm of new economy, we can identify the following perspectives for assessment of the ultimate effects: (i) economic (financial performance and capital turnover); (ii) social (welfare, safety, law observance and civic norms), (iii) ecological; (iv) customer and market; (v) operational; (vi) development (learning, innovation, growth); (vii) sustainability (resilience, vulnerability). 
By adapting the reference framework of operations strategy presented in [19] and integrating the aforementioned items of human and social capital, a contextual model was developed that combines: (i) leading factors: internal resources and external endowments; (ii) lagging factors: human and social capital; (iii) outputs - strategic capability of interest: innovativeness; (iv) outcomes: internal and external performance (Fig. 1). The latter item represents the ultimate effects, as perceived by stakeholders.

Own resources embrace all tangible and intangible assets that contribute to the human and social capital [19]. Organization refers to configuration, allocation, location, layout and links of own resources or sites. It determines the internal exchanges that enhance human and social capital. External endowments are contributions from the networking of a firm and from environment. The base of strategy is complemented with particular strategic abilities, including the dynamic and evolutionary capabilities and the innovativeness [19]. The latter item is included in the proposed model.

The model was populated with all items of human and social capital and other items suggested in literature. This way a comprehensive contextual setup of factors and effects was obtained, which enables to develop dedicated models for assessments of interdependencies of factors and effects. These can be formulated as influence maps, then possibly as functional models. Apart of the strategy process, other contexts of using the model can be suggested, like: manage and control processes, performance management, planning and controlling the development of human and social capital, innovations management, assessment of locations (along the operations strategy process), benchmarking and inter-firm comparisons (IFC), other analytics and research.

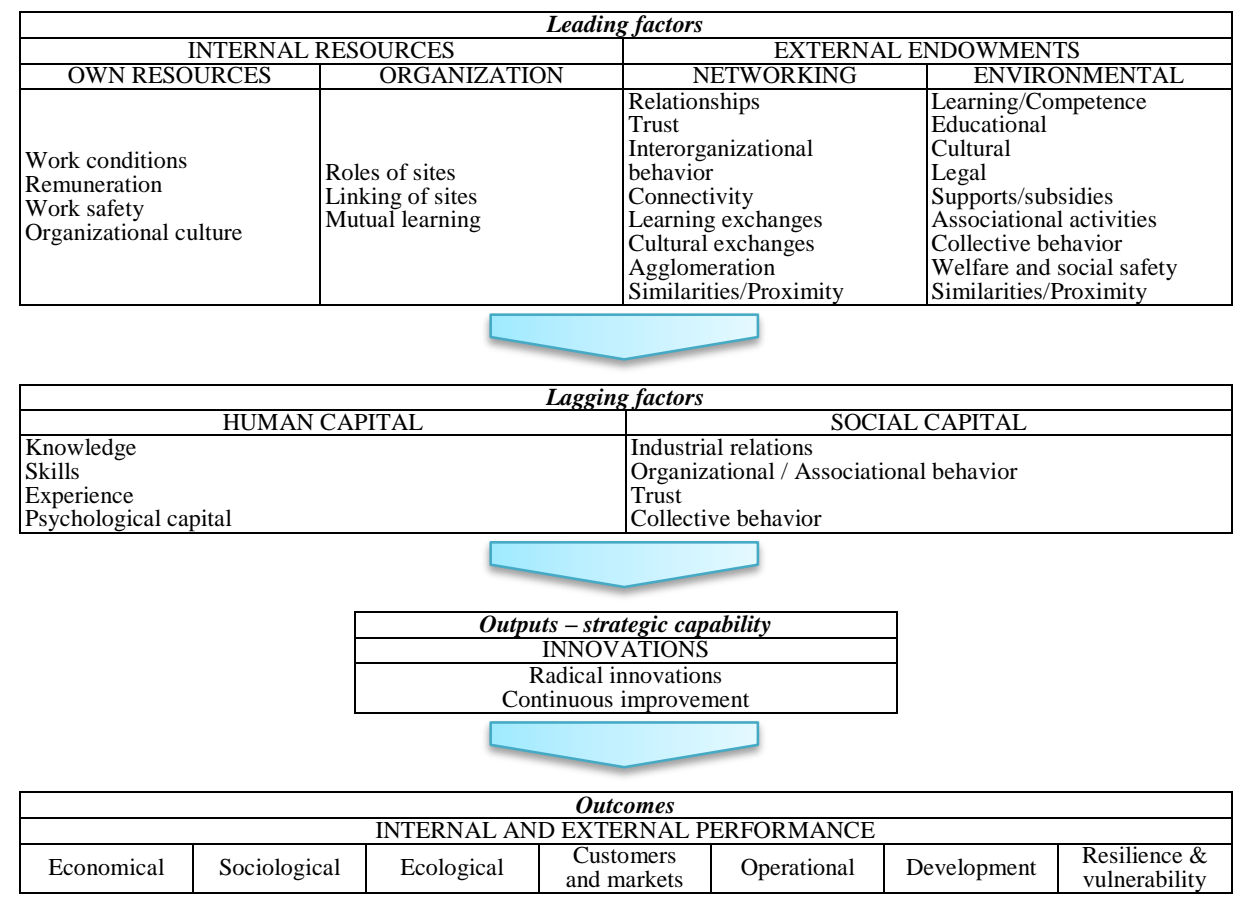

Fig. 1. Reference map of human and social conditioning of innovations - strategy view 


\section{$4 \quad$ Holistic Approach to Assessment}

Holistic approach claims that parts of a whole are in idiosyncratic interdependencies that cannot exist independently of the whole or cannot be understood without any reference to the whole, i.e. by inferring from knowledge about the regularities governing the parts $[19,20]$. Holistic assessment has to take into account: perspectives of all stakeholders, all important factors and effects, all crucial dependencies (trade-offs, offsets, discrepancies etc.) [19]. It is comprehensive but also pragmatically selective not unjustifiably reductionist and consistent.

Consistency of assessment, depending to a context, pertains to three aspects [19]. Time-consistency determines phasing of assessment, e.g. according to a strategy lifecycle (ex ante, reviewing, ex post) or innovation life-cycle (ideation, research, development, implementation, exploitation and improvement, abatement, disposal). Spatial consistency determines objects of assessment, considering the vertical (hierarchical) and horizontal extent (punctual vs. 'cradle-to-cradle'). Scope-consistency determines subjects of assessment, considering the functional (economic, social, ecological customer and market, operational, development, resilience and vulnerability) and causal extent (leading factors, lagging factors, final effects). By considering a given context the above items can be chosen accordingly. Apart of consistency, specific fits are crucial to avoid dysfunctional assessments [21]: (i) complexity fit: reflects whether the setting of assessment adequately considers the trade-offs and other critical interdependencies of factors and effects; (ii) measurement fit: consistency of applied metrics with the measured characteristics; (iii) aggregation-granularity dilemma: too detailed assessments and too aggregated measures increase the assessment effort and the difficulty to address complexities, while using too focused measures reduces diagnostic power and directing function of the assessment; (iv) informational fit: conformance with the support from legacy ICT systems; (v) methodical fit: conformance of assessment with the legacy systems and processes of manage and control.

The adequacy and correctness of assessment depend to a large extent on the competences involved. In this regard the quality of assessment relies on the dynamics and balance between technical and social controls. It is more likely that humanistic organizations that leverage reciprocity and participative approach will exhibit more competent assessments than the Weberian, leadership-based or neo-liberal organizations.

\section{$5 \quad$ Measurement of Factors and Effects}

This section outlines a framework to evaluate social and human factors of production innovations, which was derived from the model presented in section 3 . The measures were derived from literature, They are ordered according to scope, module (subrange) and subject of assessment (Table 1). Non-specific measures are not considered.

The framework provides a reference to be tailored, detailed or extended along different assessments, including: performance management, planning and controlling the development of human and social capital, management of innovations, assessment of locations, benchmarking and IFC, business and economic analytics and also research. 
Table 1. Measures to assess social and human factors of production innovations

\begin{tabular}{|c|c|c|c|}
\hline Scope & Module & Subject & Measure \\
\hline \multirow[t]{2}{*}{$\begin{array}{l}\text { External } \\
\text { endowments }\end{array}$} & Environmental & \begin{tabular}{|l|} 
Learning and cultural exchanges \\
Accessible competence \\
Education \\
Legal \\
Supports/subsidies \\
Associational activities/Collective behavior \\
Welfare \\
Social safety \\
Similarities/Proximity \\
\end{tabular} & $\begin{array}{l}\text { Checklist/Levels or ratios } \\
\text { Checklist/Levels or ratios } \\
\text { Checklist/Levels or ratios } \\
\text { Checklist } \\
\text { Checklist / Level } \\
\text { Benchmark / Level } \\
\text { Salaries < Average salary> } \\
\text { Unemployment <Ratio> } \\
\text { Benchmark } \\
\end{array}$ \\
\hline & Networking & \begin{tabular}{|l|} 
Relationships / Trust \\
Interorganizational behavior \\
Connectivity \\
Learning and cultural exchanges \\
Agglomeration \\
Similarities \\
Proximity \\
\end{tabular} & $\begin{array}{l}\text { Checklist/Level } \\
\text { Benchmark/ Reciprocity index } \\
\text { Multiplexity / Completeness } \\
\text { Checklist / Level } \\
\text { Checklist / Level / Propinquity } \\
\text { Checklist / Level / Homophily } \\
\text { Checklist / Level / Propinquity }\end{array}$ \\
\hline \multirow{2}{*}{$\begin{array}{l}\text { Internal } \\
\text { endowments }\end{array}$} & Own resources & $\begin{array}{l}\text { Work conditions } \\
\text { Remuneration } \\
\text { Work safety } \\
\text { Organizational culture } \\
\end{array}$ & $\begin{array}{l}\text { Checklist/Level } \\
\text { Benchmark/Reciprocity index } \\
\text { Checklist/Level } \\
\text { Checklist/Level }\end{array}$ \\
\hline & Organization & $\begin{array}{l}\text { Roles of sites } \\
\text { Linking of sites } \\
\text { Mutual learning } \\
\end{array}$ & $\begin{array}{l}\text { Exchanges }<\text { Checklist/Level }> \\
\text { Links }<\text { Checklist/Level }> \\
\text { Exchanges }<\text { Checklist/Level }>\end{array}$ \\
\hline \multirow{2}{*}{$\begin{array}{l}\text { Human } \\
\text { capital }\end{array}$} & Competence & Knowledge / Skills / Experience & Items $<$ Checklist $>/$ Level \\
\hline & Psychological capital & Self-efficacy/Creativity/Attitudes/Resilience & Checklist/Level \\
\hline \multirow[t]{2}{*}{$\begin{array}{l}\text { Social } \\
\text { capital }\end{array}$} & $\begin{array}{c}\text { Social } \\
\text { behavior }\end{array}$ & $\begin{array}{l}\text { Industrial relations } \\
\text { Organizational behavior } \\
\text { Trust } \\
\text { Collective and associational behavior }\end{array}$ & $\begin{array}{l}\text { Actions }<\text { Checklist/Level }> \\
\text { Items }<\text { Checklist/Level }> \\
\text { Level } \\
\text { Items }<\text { Checklist/Level }> \\
\end{array}$ \\
\hline & Collective behavior & Norms of civic behavior & Benchmark \\
\hline \multirow{4}{*}{ Innovations } & \multirow[b]{2}{*}{ Radical innovations } & Actions & Expenditures; Number of projects \\
\hline & & Outputs & \begin{tabular}{|l|} 
Patents filed/implemented \\
Benefits $<$ Checklist/Level> $>$
\end{tabular} \\
\hline & \multirow{2}{*}{ Continuous improvement } & Actions & No. of Kaizen events / Quality circles \\
\hline & & Outputs & Number or effects of improvements \\
\hline \multirow{7}{*}{ Outcomes } & Economic & Efficiency, Growth/Welfare & Percentages indicate ratios \\
\hline & Social & Work continuity / safety & Percentages indicate ratios \\
\hline & Ecological & $\begin{array}{l}\text { Consumption/depletion of natural resources } \\
\text { Waste /Pollution }\end{array}$ & $\begin{array}{l}\text { Eco-efficiency /Intensity ratios } \\
\text { /Percentages indicate ratios }\end{array}$ \\
\hline & Customer \& market & Competitiveness & Percentages indicate ratios \\
\hline & Operational & Efficiency / Costs / Quality & Level / Ratios \\
\hline & Development & Intellectual capital / Exports & Percentages indicate ratios \\
\hline & $\begin{array}{l}\text { Resilience and } \\
\text { vulnerability }\end{array}$ & $\begin{array}{l}\text { Risks } \\
\text { Contingencies }\end{array}$ & $\begin{array}{l}\text { Risk metrics } \\
\text { Checklist / Level }\end{array}$ \\
\hline
\end{tabular}

\section{A Method of Assessment}

This section outlines a method to assess social and human factors of production innovations. The phasing of the method was adapted from the pattern 'objectives-contextperspectives-modules-subjects-metrics-methods'. The method itself is derived from the model presented in section 3 and assumes using the measurement framework presented in section 5. The holism of assessment is secured through including indispensable steps to identify all factors and effects as well as by considering important dependencies between them. In regard to the consistency of assessment, the method relies on involvement of the relevant competencies, which depends on the dynamics and balance between technical and social controls in the focal organization.

The method assumes seven phases (Fig. 2). Firstly objectives and context are contextualized. Normally objectives are derived from the strategy. Then perspectives of assessment are defined in regard to the setup of stakeholders and the constraints identified, accordingly. Altogether the first two phases enable to obtain in a holistic way the base for further assessment. The third phase consists in identification, then causal 
modelling of all factors and effects. Next, a structure of measures is developed, then functional models of the domain. Fifth phase provides input information to the assessment through data collection analytics. The evidence for assessment is then verified, possibly modified, and approved. The last phase consists in implementation of results through deployment, then monitoring and reactive (corrective) activities.

\begin{tabular}{|c|c|c|}
\hline \multicolumn{3}{|c|}{ Phase 1} \\
\hline \multicolumn{3}{|c|}{ Identification of context } \\
\hline \multicolumn{3}{|c|}{$\begin{array}{c}\bar{y} \\
\text { Phase } 2\end{array}$} \\
\hline \multicolumn{3}{|c|}{ Identification of constraints } \\
\hline \multicolumn{3}{|c|}{ Phase 3} \\
\hline Identification of factors, effec & itcomes & ects and outcomes \\
\hline \\
\hline \multicolumn{3}{|c|}{ Identification of modules, subjects and measures } \\
\hline \multicolumn{3}{|c|}{ Phase 5} \\
\hline Data collection and processing & Data Calculations / Simulation & Data analytics \\
\hline \multicolumn{3}{|c|}{$<>$} \\
\hline \multicolumn{3}{|c|}{ Phase 6} \\
\hline Verification & Modification & Approval \\
\hline \multicolumn{3}{|c|}{ 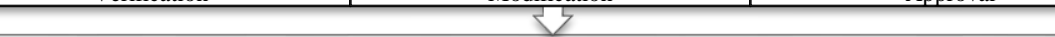 } \\
\hline Deployment & Monitoring & Correction \\
\hline
\end{tabular}

Fig. 2. Phased procedure of assessing human and social factors of production innovations

The above reference framework can be customized and detailed to a specific procedure in accordance with the current perspective and context (as indicated in section 3 ), the required aspects of consistency (section 4) and measurement (section 5), and the purpose of using the method determined by the context of its use (section 3 ). The method exemplifies a full-blown holistic approach to assessment.

\section{$7 \quad$ Summary and Further Work}

This paper proposes a method to assess human and social factors of production innovations. It is based on a model derived from a strategy framework, which is based on the resource-based view. The key constructs in the model are human and social capital. The model is equipped with a measurement framework. The solution is derived from the existing research evidence. The design of method assures holistic assessment through comprehensive and multi-perspective viewing of the domain, consideration of all important factors, effects and complexities, as well as integrity of assessment.

The contribution of this paper lies in an original holistic approach to assessment of human and social factors of innovations. The proposal is sound, as it synthesizes the existing research evidence. It is also viable and universal in the sense that it matches to various contexts of its use. As yet the approach relies on theoretical justification and requires further validation. Another need for further examine the factors and effects and their interdependencies using the phenomenological research. The empirical validation of the method provides another challenge. 


\section{References}

1. Luthans, F., Luthans, K.W., Luthans, B. C.: Positive psychological capital: Beyond human and social capital. Business Horizons, 47/1, pp 45-50 (2004)

2. Dakhli, M., De Clercq, D.: Human Capital, Social Capital and Innovation: A MultiCountry Study, Universiteit Ghent Working Paper, No. 2003/211 (2003)

3. Becker, G.: Human capital. National Bureau of Economic Research, New York, (1964)

4. Gimeno, J., Folta, T., Cooper, A., Woo, C.: Survival of the fittest? Entrepreneurial human capital and the persistence of underperforming firms. Administrative Science Quarterly, vol. 42, pp. 750-784 (1997)

5. Coleman, J. S.: Social capital in the creation of human capital. American Journal of Sociology, vol. 94, pp. S95-S120 (1988)

6. Barney, J. B.: Firm Resources and Sustained Competitive Advantage. Journal of Management, 17/1, pp. 99-120 (1991)

7. Strzelczak, S.: Modularized innovations in cluster-based innovation networks in China. In: Brzóska, J., Pyka, T. (eds.), Modernity of industry and services under crisis and new challenges pp. 229-242, TNOiK Katowice, Katowice, (2013)

8. Taylor, R., Morone, P.: Innovation, Networks and Proximity: An Applied Evolutionary Model. In: Proceedings of the $4^{\text {th }}$ European Meeting on Applied Evolutionary Economics (EMAEE), The Netherlands, 19-21 May 2005 (2005)

9. Harter, J.K., Schmidt, F.L., Hayes, T.L.: Business-unit Level Relationship Between Employee Satisfaction, Employee Engagement, and Business Outcomes: A Meta-analysis. Journal of Applied Psychology, 87/2, pp. 268-279 (2002)

10. Nahapiet, J., Ghoshal, S.: Social capital, intellectual capital and the organizational advantage. Academy of Management Review, vol. 23, pp. 242-266 (1998)

11. Prais, S.J.: Productivity, education and training: an international perspective. Cambridge University Press, Cambridge (1995)

12. Adler, P.S., Kwon, S.-W.: Social capital: Prospects for a new concept. Academy of Management Review, vol. 27/1, pp. 17-40 (2002)

13. Hashimoto, M.: The Industrial Relations System in Japan: an Interpretation and Policy Implications. Managerial and Decision Economics, vol. 12, pp. 147-157 (1991)

14. Dzinkowski, R.: The value of intellectual capital. J. Business Strategy, 21/4, pp. 3-4 (2000)

15. Lai, G., Lin, N., Leung, S.: Network resources, contact resources, status attainment. Social Networks, vol. 20, pp. 159-178 (1998)

16. Barrat, A., Berthélemy, M., Vespignani, A.: Dynamical processes on complex networks. Cambridge University Press, Cambridge (2010)

17. Dyer J.H., Singh H.: The relational view: cooperative strategy and sources of interorganizational competitive advantage. Acad. Management Review, 23/4, pp. 660-679 (1998)

18. Porter, M.E.: Competitive Advantage, Agglomeration Economies, and Regional Policy. International Regional Science Review, 19/1-2, pp. 85-94 (1989)

19. Strzelczak S., Integrated Assessment of Operations Strategy. Scientific Papers of Silesian University Technology, Series: Organization \& Management, No. 116, pp. 95-108 (2018)

20. Marciniak, S.: Evaluation of Functioning of an Innovating Enterprise Considering the Social Dimension. In: Lödding, H., Riedel, R., Thoben, K.-D., von Cieminski, G., Kiritsis, D. (eds.), The Path to Intelligent, Collaborative and Sustainable Manufacturing. LNCS, vol. 513. Springer, Cham, pp. 372-379 (2017) doi: 10/1007/978-3-319-66923-6

21. Strzelczak S.: Integrated Assessment of 'Green-Lean' Production. International Journal of Automation Technology, 11/3, pp. 815-828 (2017) doi: 10.20965/ijat.2017.p0815 